\title{
砕石粉の含水状態の指標および密度の試験方法に関する検討 STUDY ON TEST METHODS OF WATER ABSORPTION AND DENSITY OF CRUSHED STONE FINES
}

\author{
大橋正治*, 田村 博** \\ Masaharu OHASHI and Hiroshi TAMURA
}

\begin{abstract}
Studies on test methods of water absorption and density of crushed stone fines as additives for concrete were carried out, and the following two findings were obtained.

1. The percentage of absorbed water of the crushed stone fines in the moisture-saturated condition is available as an index of the effective water in a concrete mixture using the fines.

2. The Le Chatelier flask conformed to JIS R 5201. is suitable for measuring the density of the crushed stone fines as an additive for concrete.
\end{abstract}

Keywords: Crushed stone fines, Water content per unit volume of concrete, Percentage of absorption, Percentage of absorbed moisture, Density

砕石粉, 単位水量; 吸水率, 吸着水率, 密度

\section{1.はじめに}

本研究では、砕石・砕砂の製造過程（図 1 参照）で副産される砕

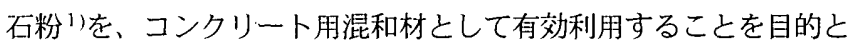
し、そのための砕石粉の品質規準について検討している2゙。本報で は、コンクリート調合における単位水量算出の際の、普通骨材でい う表乾状態に相当する砕石粉の含水状態の指標および密度の試験方 法とコンクリート実験の結果について述べる。

単位水量は、「フレッシュコンクリート $1 \mathrm{~m}^{3}$ 中に含まれる水量。 ただし、骨材中の水量は含まない」と定義されている3)。日常のコ ンクリート製造においては、時々刻々と変化する骨材の含水状態を 把握し、あらかじめ JIS A 11094)によって求めておいた吸水率をも とにして有效含水量あるいは表面水量に相当する水量を補正しなが ら練り混ぜている。

本研究で対象としている乾式の製造過程で集塵される砕石粉は、 粒径分布範囲 $0.6 \mathrm{~mm} \sim 1 \mu \mathrm{m}, 50 \%$ 粒径 $50 \mu \mathrm{m} \sim 10 \mu \mathrm{m}$ 程度 ${ }^{2}$ の細 骨材より細かくセメントよりやや粗い粒度である。この砕石粉の含 水状態は、製造過程における自然環境の変化や保管状態によって変 化するので、コンクリート用混和材として使用しコンクリートを練 り混ぜる際には、普通骨材と同様に、砕石粉の含水状態に応じた水 量の補正が必要であると考える。，そのために活、単位水量に含まな

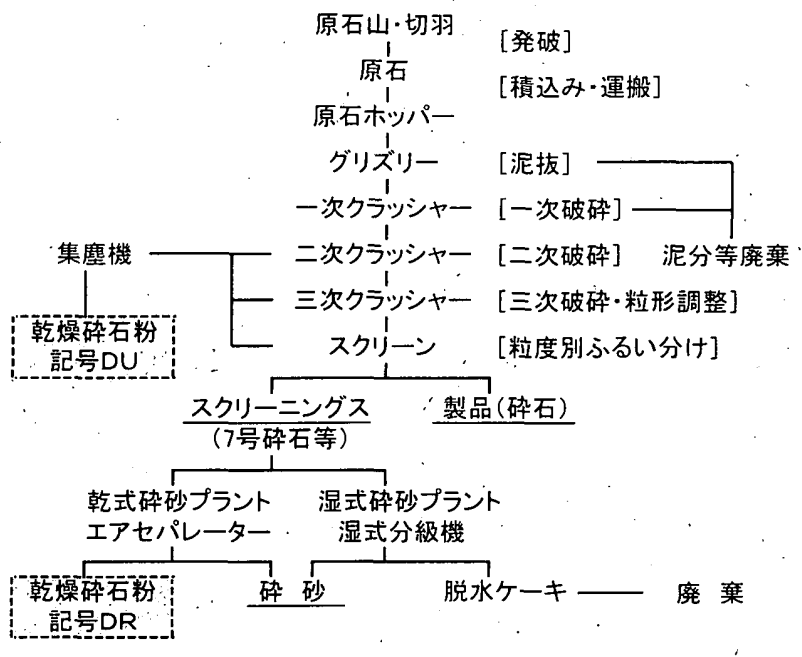

図 1 砕石・砕砂の製造工程の一例 1)

い砕石粉中の水と単位水量に含む水とに区分けするための、有効水 量に関する含水状態の指標を定義しなければならないが、粒径分布 範囲の異なる砕石粉に、細骨材に対する現行のJIS試験力法を適朋
*㒋日本建築総合試験所材料部中央試験室

** (期日本建築総合試験所材料試験室 工博
Construction Materials Lab., Central, Material Dept. General Building Research Corporation of Japan

Material Dept., General Building Research Corporation of Japan, Dr. Eng. 
するには無理がある。またそれと同時に、砕石粉の調合計算に用い る密度についても定める必要がある。この調合計算に用いる密度は、 フレッシュコンクリート中での、砕石粉の内部と考えられる水を含 んだ状態の見掛けの密度である。

\section{2. 砕石粉の有効水量に関する含水状態の指標について}

普通骨材の含水状態は、図 $2^{5)}$ に示したように、a)絶対乾燥状態、 b)気乾状態、c)表面乾燥飽水（表乾）状態および d)湿潤状態に区分 され、c)表乾状態を、コンクリート調合上の単位水量に含まない骨 材中の水と単位水量とに区別するための、有効水量に関する含水状 態の指標として定義している。この表乾状態を図 3 に示した粒子断 面の例のに当てはめると、粒子表面の滑らかな部分は乾いているが、 表層部の裂け目や割れ目，洞穴あるいは凹み部分にはある程度の水 分が保たれているものと考えられ、それらの粒子表層部に保たれた 水も吸水量に含まれる。一方、当該の試験方法では脱気できない、 粒子内部の空洞や粒子表層の洞穴あるいは割れ目などにも存在する と考えられる空隙は、粒子の一部とみなされることになる。

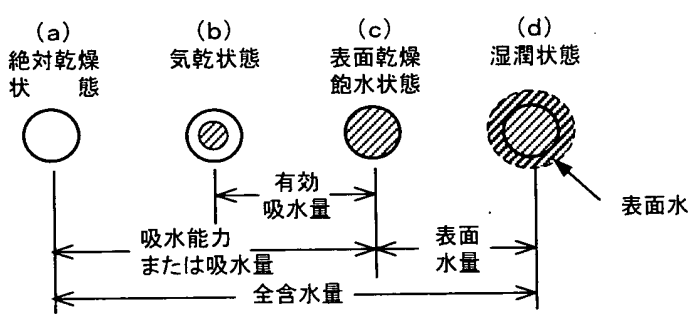

図 2 骨材の含水状態 5

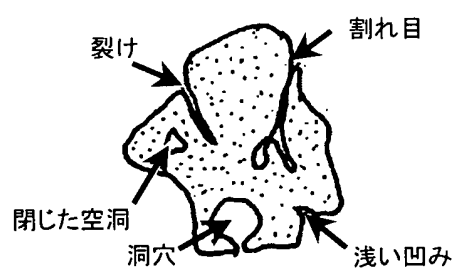

図 3 粒子断面の例 ${ }^{6}$

紐骨材の各粒度群別の吸水率試験結果を表 1 に示す。試験には九 州玄界灘唐津産海砂ならびに兵庫県家島産砕砂の 2 種類の細骨材を 用いた。それぞれの細骨材を各粒度群別にふるい分け、さらに水洗 いしたものを試験試料とし、JIS A 1109 の方法に従って各粒度群別 の吸水率を求めた。なお、同法では、細骨材を 24 時間水浸して吸 水させた後、暖かい風を静かに送りながら均等に乾燥させ、細骨材 の表面に幾分表面水があるときに、規定の方法で試料をフローンコ ーンに詰めこれを引き上げる。その作業を、試料を徐々に乾燥させ ながら繰り返し、フローコーンを引き上げたときに細骨材のコーン がはじめてスランプしたとき、表乾状態であるとしている。ただし、 この方法では、細かい単粒は乾いているように見えてスランプせず、 粗以単粒は濡れているように見えてスランプする7ため、今回は視 察による判断も加味して表乾状態を決定した。なお、同表には、既 報告から矢作川産川砂の試験結果 ${ }^{8)}$ も抜粋・記載した。また、それ らの粒度群別の吸水率試験結果を $\mathrm{y}$ 軸に、各粒度群の通過するふる いと留まるふるいの呼び径の平均值（ただし、ふるいの呼び径 $0.15 \mathrm{~mm}$ 以下の場合はその $1 / 2)$ を単純にその粒度群の直径として
算出した球の表面積／球の体積（S/N 值）を各粒度群の指標とし $\mathrm{x}$ 軸にとって図 4 に示す。同図で右肩上がりの傾向を示す粒度の吸水 率は、粒子の体積よりも表面積の影響が強くなることを示し、試験 に用いた砕砂では $0.6 \sim 0.3 \mathrm{~mm}$ より小さい粒度群でその傾向となつ た。本研究で対象としている砕石粉の粒径分布範囲は $0.6 \mathrm{~mm} \sim 1$ $\mu \mathrm{m}$ であることから、その砕石粉の吸水能力は、粒子表層部に保た れて粒子内部とみなされる水に着目するのがよい考えられた。

表 1 細骨材の各粒度群別の吸水率試験結果

\begin{tabular}{|c|c|c|c|c|c|}
\hline \multicolumn{2}{|c|}{ 試料の粒度群 (mm) } & \multirow{3}{*}{$\begin{array}{c}\text { 球表面筫(S) } \\
\text { 球体櫝 }(\mathrm{V}) \\
\left(\mathrm{mm}^{2} / \mathrm{mm}^{3}\right)\end{array}$} & \multirow{2}{*}{\multicolumn{3}{|c|}{$\begin{array}{c}\text { 吸 水 率 } \\
(\%)\end{array}$}} \\
\hline \multirow{2}{*}{$\begin{array}{l}\text { 通過する } \\
\text { ふるい目 }\end{array}$} & \multirow{2}{*}{$\begin{array}{c}\text { 留まる } \\
\text { ふるい目 } \\
\end{array}$} & & & & \\
\hline & & & 砕 砂 & 海 吵 & 川 砂 ${ }^{3)}$ \\
\hline 10 & 5 & 0.8 & - & 3.02 & 0.86 \\
\hline 5 & 2.5 & 1.6 & - & 1.34 & 0.80 \\
\hline 2.5 & 1.2 & 3.2 & 1.31 & 1.58 & 1.11 \\
\hline$\cdot 1.2$ & 0.6 & 6.7 & 0.96 & 0.76 & 1.29 \\
\hline 0.6 & 0.3 & 13.3 & 1.08 & 1.10 & 1.77 \\
\hline 0.3 & 0.15 & 26.7 & 1.51 & 1.59 & 2.04 \\
\hline 0.15 & - & 80.0 & 4.31 & - & - \\
\hline
\end{tabular}

主）通過するふるい目と留まるふるい目の呼称寸法の平均値を直径とする、 球の表面積(S)/球の体積(V)。ただし、呼称寸法 $0.15 \mathrm{~mm}$ を通過する粒度群 については球の直径を $0.075 \mathrm{~mm}$ で計算。

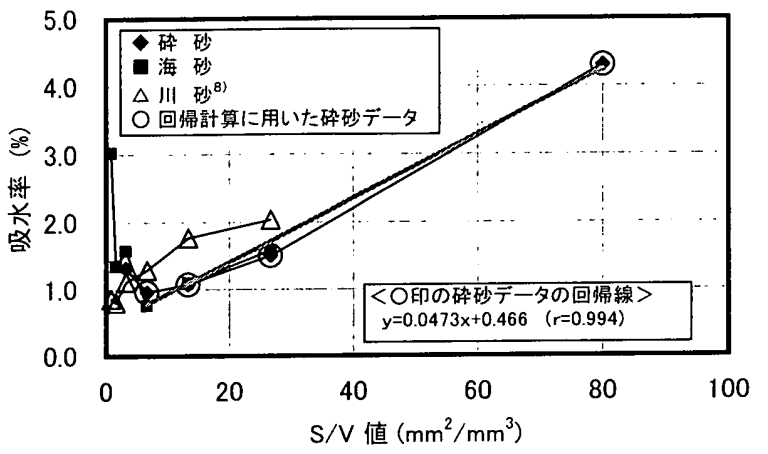

図4 吸水率と細骨材の各粒度群に対する $\mathrm{S} / \mathrm{V}$ 值との関係

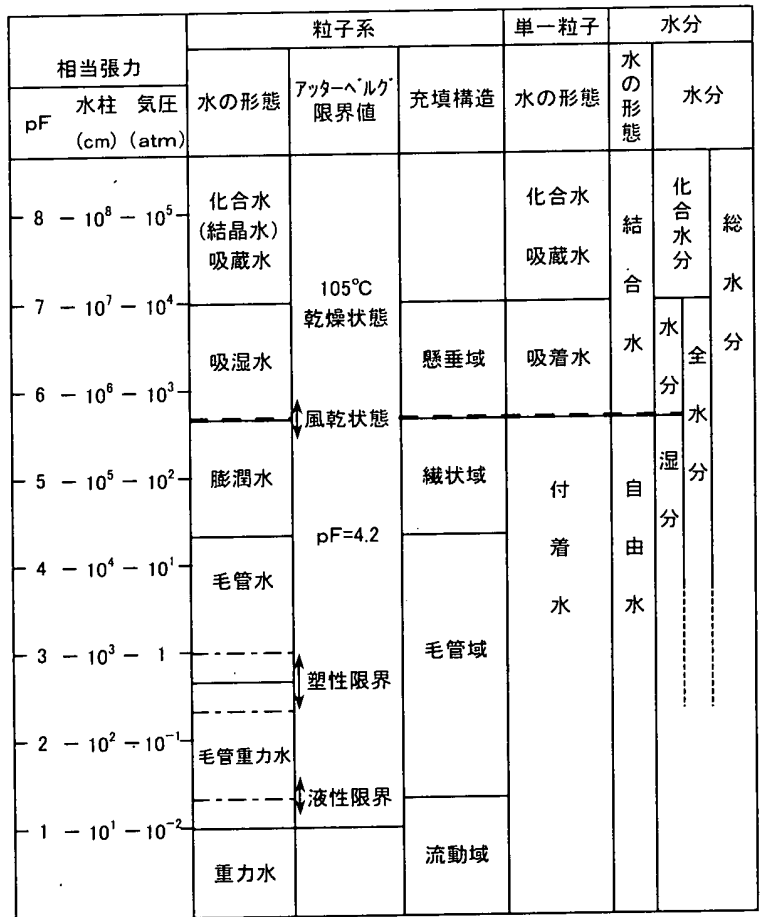

図 5 粉粒体における単一粒子の水の存在形態 6 
粉粒体における水の状態を図 $5^{6}{ }^{6}$ に示す。同図の水の形態では、 化合水亡吸蔵水, 吸着水 (吸湿水) までが結合水と考えられており、 このうち化合水と吸蔵水は、 $105^{\circ} \mathrm{C}$ 乾燥状態（図 2 中の絶対乾状 態相当）で粒子内部に存在する水である。したがって、コンクリー 卜用混和材として用いる碀石粉では、図 4 中の風乾状態を湿気飽和 状態までもっていき、この湿気飽和状態下で粒子の結合水と考えら れる吸着水量を、コンクリート骨材でいう吸水量に置き換えれば良 いと思われる。なお、吸着水量は、粒子の比表面積に強く依存する ことが知られている6i。

\section{3. 砕石粉の吸着水率の測定}

吸着水率の試験方法としての適用性についての検討を、表 2 に示 した 12 種類の砕石粉および、比較用石粉として石灰石粉と 2 種類 の粘土粉を用いて行った。試験は、図6のフローチャートにしたよ うに、まず試料の絶乾状態の質量を測定し、その後、相対湿度 $95 \%$ 以上の多湿室内で、試料の入った容器の内面が結露しないように静 置して表面から湿気を試料に吸着させ、質量がほぼ一定となったと きの試料の質量から水分吸着量を求め、吸着水率を算出した。

試験結果を表 2 および図 7 に示す。なお、本方法では、砕石粉が ほぼ一定質量となるまでに約 3 週間を要した。

窒素吸着法にようて測定した比表面積と吸着水量の関係を図 8 に メチレンブルー吸着量 ${ }^{2)}$ と吸着水率の関係を図 9 に示す。それらの 四から、窒素吸着法によって測定した比表面積およびメチレシブル 一吸着量のいずれもが、吸着水率との間に正の相関関係があった。 ただし、砕石粉のみに注目すれば、窒素吸着法によって測定した比 表面積と吸着水率の関倸は明確でなかった。

以上の結果から、本法による吸着率試験方法を砕石粉に適用する ことは可能であるが、試験結果を得るまでには 3 週間程度の長時間 を要すること、および、試験期間 1〜2 日程度の短時間で求められ るメチレンブル一吸着量から砕石粉の吸着水率を精度良く推定する ことが可能なことが確認された。

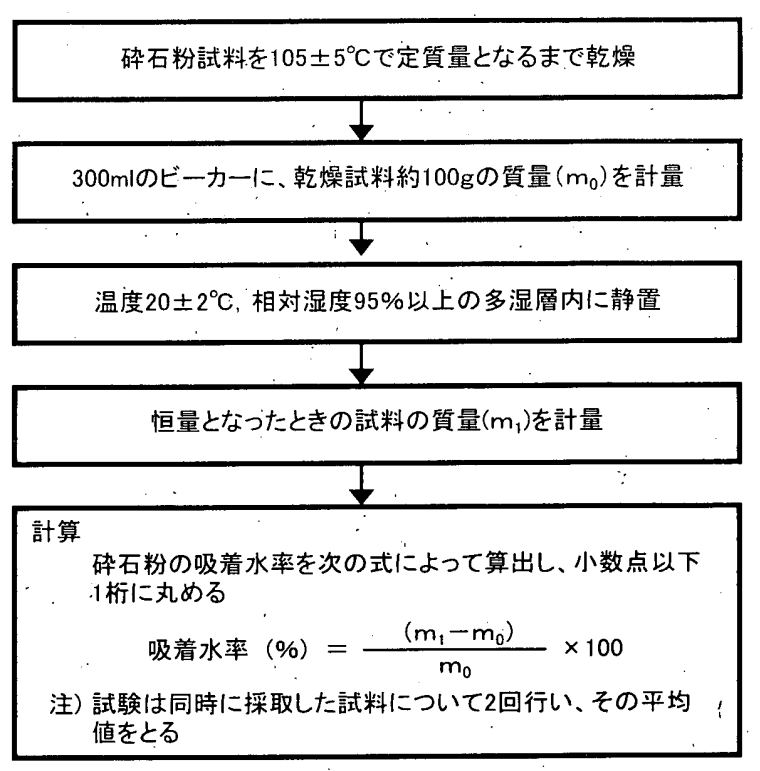

図 6 砕石粉の吸着水率試験の手順

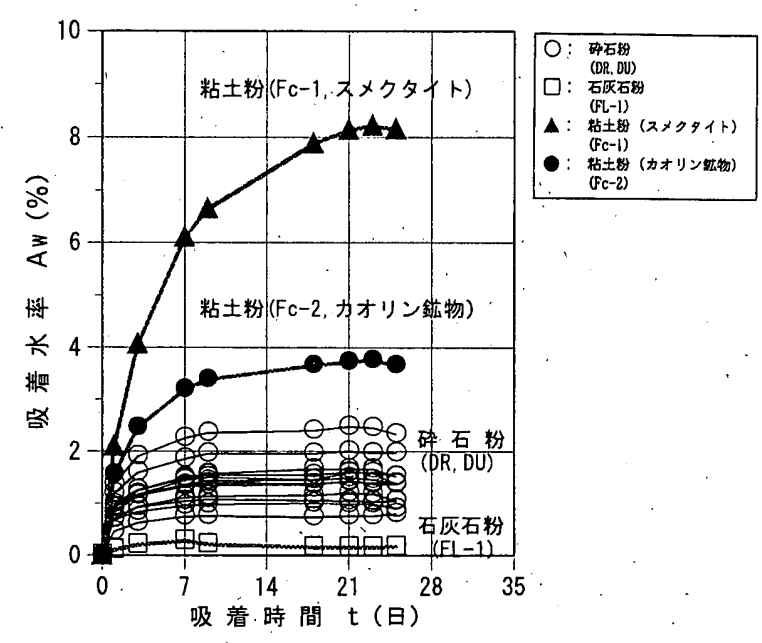

図 7 石粉の吸着水率試験結果

表2 石粉の種類, 化学組成, 比表面積, メチレシブルー吸着量および吸着水率測定結果

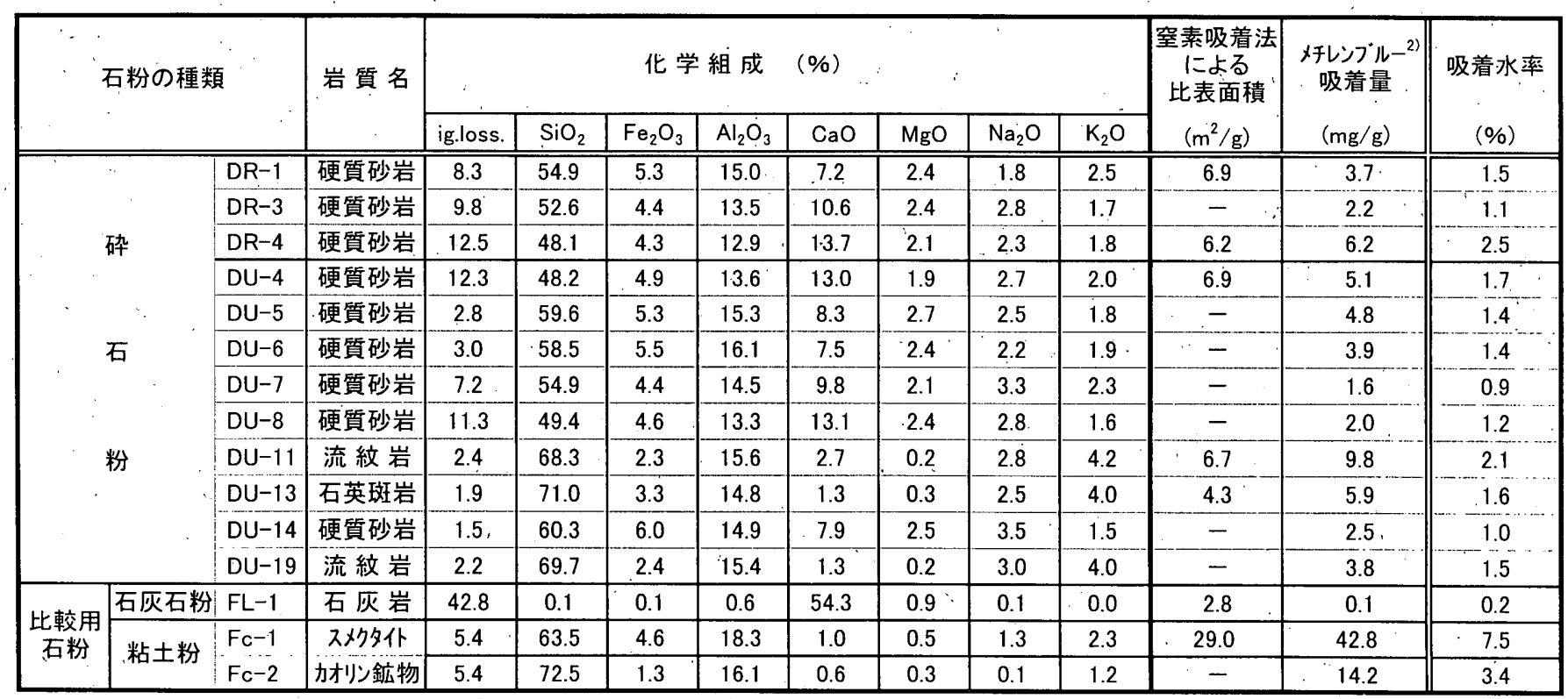




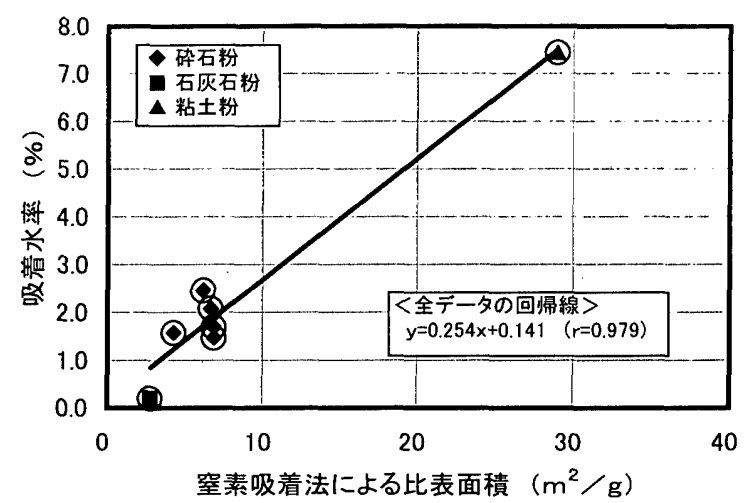

図 8 窒素吸着法による比表面積と吸着水率の関係

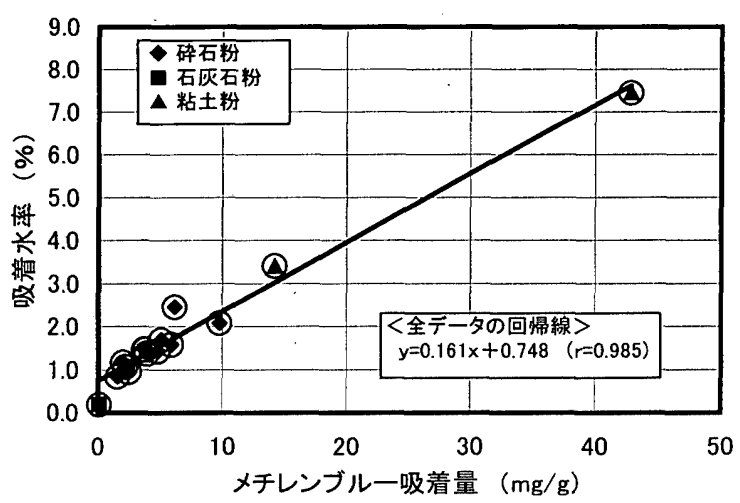

図 9 メチレンブルー吸着量 ${ }^{2)}$ と吸着水率の関係

\section{4. 密度試験方法の検討}

粒子密度の測定方法は、液浸法と気体容積法に大別され、コンク リート用材料の密度試験としては液浸法が一般的に採用されている。 本報では、砕石粉の密度試験方法として、Le Chatelier 比重びん法 およびピクノメータ一法を取り上げ、比較検討した。いずれも浸夜 法である。Le Chatelier 比重びん法はセメントの密度を求める方法 として、JIS R 5201 $\left.{ }^{9}\right)$ に、ピクノメーター法は土の密度を求める方 法として JIS A120210にそそれぞれ規定されており、それらの方法に 準拠して密度試験を実施した。

密度試験に用いた石粉は、先の吸着水率の測定に用いたものと同 じ、 12 種類の砕石粉ならびに比較用石粉としての石庅石粉および 2 種類の粘土粉である。

試験結果を表 3 に、両者の比較を図 10 に示す。試験に用いた多 くの䂶石粉および石灰石粉では、Le Chatelier 比重びん法で求めた 密度が、ピクソメーター法で求めた密度と同等か僅かに小さくなる 程度であったのに対し、哗石粉 DR-3 および DR-4 や、特に粘土粉 Fc-1 および Fc-2 では，Le Chatelier 比重びん法で求めた密度が、 ピクノメーター法で求めた密度を下回っていた。

ピクノメーター法では、湯煎法によって脱気したので粉体の真密 度に近い值が得られていると考えられる。一方、Le Chatelier 比重 びん法では浸液中に浸け、振倒・転倒することによって脱気してい るので、完全な脱気は望めない。ピクノメーター法で求めた密度を 下回っていた砕石粉や粘土粉には、その表層部に、脱気できない空 隙を保持した洞穴や割れ目などが存在したからであると推察する。

コンクリート分野においては見掛け密度が使われる ${ }^{11}$ 。その材料 がフレッシュコンクリート中におかれた状態の見掛けの密度がコン
表 3 石粉の密度試験結果

\begin{tabular}{|c|c|c|c|c|}
\hline \multirow{2}{*}{\multicolumn{3}{|c|}{ 粉体の種類 }} & \multicolumn{2}{|c|}{ 密度 $\left(\mathrm{g} / \mathrm{cm}^{3}\right)$} \\
\hline & & & \multirow{2}{*}{$\begin{array}{l}\text { Le Chatelier } \\
\text { 比重びん法 } \\
2.71\end{array}$} & \multirow{2}{*}{ 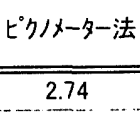 } \\
\hline \multirow{5}{*}{\multicolumn{2}{|c|}{ 砕 }} & DR-1 & & \\
\hline & & $\mathrm{DR}-3$ & 2.63 & 2.71 \\
\hline & & DR-4 & 2.61 & 2.71 \\
\hline & & DU-4 & 2.70 & 2.72 \\
\hline & & DU-5 & 2.74 & 2.75 \\
\hline \multirow{3}{*}{\multicolumn{2}{|c|}{ 石 }} & DU-6 & 2.73 & 2.75 \\
\hline & & DU-7 & 2.70 & 2.7 \\
\hline & & DU-8 & 2.73 & 2.73 \\
\hline \multirow{4}{*}{\multicolumn{2}{|c|}{ 粉 }} & DU-11 & 2.62 & 2.66 \\
\hline & & DU-13 & 2.66 & 2.69 \\
\hline & & DU-14 & 2.76 & 2.77 \\
\hline & & DU-19 & 2.64 & 2.66 \\
\hline \multirow{3}{*}{$\begin{array}{c}\text { 比較用 } \\
\text { 石粉 }\end{array}$} & 石灰石粉 & $\mathrm{FL}-1$ & 2.71 & 2.71 \\
\hline & \multirow{2}{*}{ 粘土粉 } & $\mathrm{Fc}-1$ & 2.46 & 2.68 \\
\hline & & $\mathrm{Fc}-2$ & 2.59 & 2.73 \\
\hline
\end{tabular}

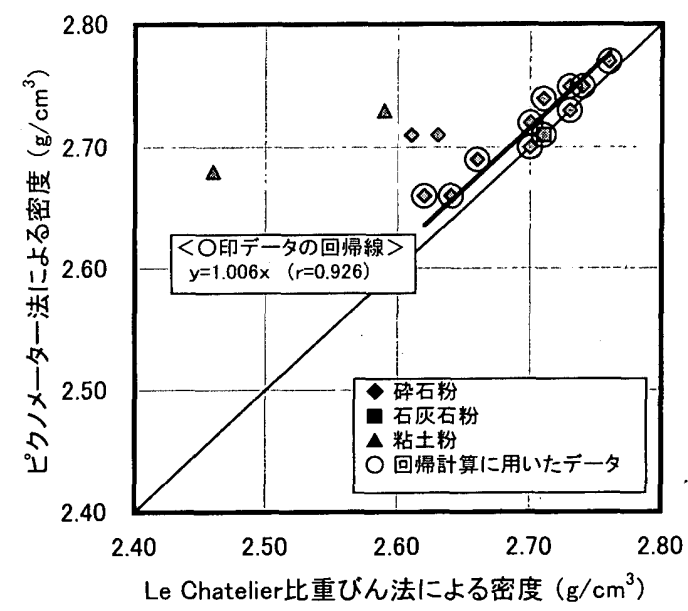

図 10 密度試験結果の比較

クリートを調合する上で必要亡される。したがって、過度な脱気を 行わないJIS R 5201 に規定するLe Chatelier 比重びん法は、コ ンクリート用混和材として用いる砕石粉の密度試験に適していると 考えられる。

なお、相対湿度 $95 \%$ 以上の多湿霩囲気中での砕石粉の水分吸着均 衡状態の密度 $\rho_{\mathrm{Aw}}\left(\mathrm{g} / \mathrm{cm}^{3}\right)$ は、そのときの吸着水がすべて乾燥状態 の粒子表面外側に結合すると考元、Le Chatelier 比重びん法により 求めた乾燥状態の密度 $\rho \mathrm{D}\left(\mathrm{g} / \mathrm{cm}^{3}\right)$ と吸着水率 $\mathrm{A}_{\mathrm{w}}(\%)$ から下式 によって算出した。

$$
\rho_{\mathrm{Aw}}=\rho_{\mathrm{D}}\left(1+\mathrm{A}_{\mathrm{w}} / 100\right) /\left(1+\rho_{\mathrm{D}} \times \mathrm{A}_{\mathrm{w}} / 100\right)
$$

吸着水率と Le Chatelier 比重びん法による密度の関係を図 11 に 示す。吸着水率と Le Chatelier 比重びん法による密度には負の一 次相関関倸が確認された。また、コンクリート用混和材としては適 さないと考えられる 2 種類の粘土は、いずれも吸着水率が大きく密 度が小さかった。このことから、この吸着水率と密度は、哗石粉の 品質を判定するための指標となる可能性が高いものと思われる。 


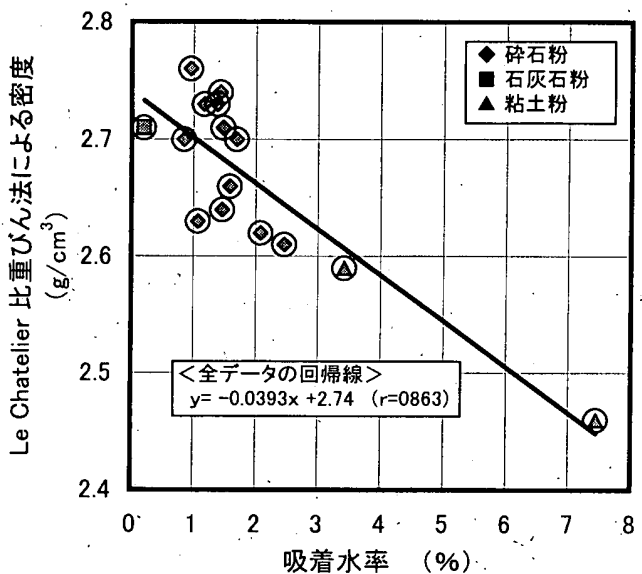

図 11 吸着水率と Le Chatelier 比重びん法による密度の関係

\section{5. 石粉使用コンクリートによる実験結果}

コンクリート用混和材としての砕石粉の用途に、流動化コンクリ 一トあるいは高性能 $\mathrm{AE}$ 減水剤を用いたコンクリートでコンクリー ト中の粉体量が不足し分離傾向を示す場合の、分離低減材が挙げら れる。そこで、そのような場合に該当すると思われた調合のコンク リート（基準コンクリート）と、およびこれに 12 種類の砕石粉あ るいは比較用石粉としての石灰石粉ならびに 2 種類の粘土粉を使用 した、合計 15 種類の石粉使用コンクリートを試し練りした。
使用材料を表 4 に、コンクリート調合を表 5 に示す。石粉の使用 量 $0.016 \mathrm{~m}^{3} / \mathrm{m}^{3}$ は、細骨材中の粒径 $0.75 \mathrm{~mm}$ 以下の微粒分量に換算 して JIS 5303 付属書 1 (規定)12)の砂に対するコンクリートの表面 がすりへり作用を受けない場合の上限値 $5 \%$ にほぼ相当する量であ る。また、目標スランプ $18 \pm 1 \mathrm{~cm}$ が得られるように高性能A E 減 水剤の使用量を調整した。なお、使用し時の各石粉の含水率は表 6 に示したとおりであり、コンクリート練り混ぜの際には前述の吸着 水率をもとに調合を水量補正した。

フレッシュコンクリートの性状および圧縮強度試験結果を表 6 に 示す。目標スランプを得るために必要とした高性能 $\mathrm{AE}$ 隇水剤の使 用量を粉体に対する質量比 $((\mathrm{C}+\mathrm{F}) \times \%)$ で示すと、砕石粉を使用 しない基準コンクリートならびに砕石粉や石灰石粉を使用したコン クリートでは、いずれもが同じ 1.0\%であった。一方、粘士粉 FC-1 および FC-2 を使用したコンクリートではそれぞれ 2.0\%および $2.8 \%$ と多量の高性能A E 減水剤を必要とした。また、ブリーディン グ量は、基準コンクリートの $0.27 \mathrm{~cm}^{3} / \mathrm{cm}^{2}$ に対して、石灰石粉を使 用したコンクリートは $0.18 \mathrm{~cm}^{3} / \mathrm{cm}^{2}$ 、砕石粉および粘土粉を使用し たコンクリートでは $0.08 \sim 0.12 \mathrm{~cm}^{3} / \mathrm{cm}^{2}$ といずれの石粉使用コンク リートも低減されたことから、石粉を使用したことによるコンクリ 一トの分離抵抗性改善効果が確かめられた。

コンクリートの圧縮強度と、調合設計時の空気量 $4.5 \%$ 之試験値 の差で表した空気量との関係を図 12 に示す。
表 4 使·用材 料

\begin{tabular}{|c|c|}
\hline セメント & $\begin{array}{l}\text { 普通ポルトランドセメント } \\
\text { 密度 } 3.15 \mathrm{~g} / \mathrm{cm}^{3}\end{array}$ \\
\hline 細骨材 & $\begin{array}{l}\text { 岡山県日比産海砂 } \\
\text { 絶乾密度 } 2.54 \mathrm{~g} / \mathrm{cm}^{3} \\
\text { 吸水率1.48\% }\end{array}$ \\
\hline 粗骨材 & $\begin{array}{l}\text { 大阪府長尾山産砕石 } \\
\text { (确石2005) } \\
\text { 絶乾密度 } 2.69 \mathrm{~g} / \mathrm{cm}^{3} \\
\text { 吸水率 } 1.48 \%\end{array}$ \\
\hline 混和剂 & $\begin{array}{l}\text { ポリカルボン酸系 } \\
\text { 高性能AE減水刘 }\end{array}$ \\
\hline 砕石粉 & $\begin{array}{l}\text { DR-1, DR-3, DR-4 } \\
\text { DU-4, DU-5, DU-6 } \\
\text { DU-7, DU-8, DU-11 } \\
\text { DU-13, DU-14, DU-19 }\end{array}$ \\
\hline $\begin{array}{l}\text { 比較用 } \\
\text { 石粉 }\end{array}$ & $\begin{array}{l}F L-1 \text { (石灰石粉) } \\
F_{c}-1, F c-2 \text { (粘土粉) }\end{array}$ \\
\hline
\end{tabular}

表 6 石粉使用コンクリートの試験結果

\begin{tabular}{|c|c|c|c|c|c|c|c|c|c|}
\hline \multirow{2}{*}{\multicolumn{3}{|c|}{$\begin{array}{c}\text { コンクリートの種類 } \\
\text { (石粉の種類) }\end{array}$}} & \multirow{2}{*}{$\begin{array}{c}\text { 使用時の } \\
\text { 含水率 } \\
(\%) \\
\end{array}$} & \multirow{2}{*}{$\begin{array}{l}\text { 混和剤 } \\
\text { 使用量 } \\
\text { (C+F) } \times \% \\
\end{array}$} & \multirow{2}{*}{$\begin{array}{c}\text { スランプ } \\
(\mathrm{cm})\end{array}$} & \multirow{2}{*}{$\begin{array}{l}\text { 空気量 } \\
(\%)\end{array}$} & \multirow{2}{*}{$\begin{array}{c}\text { フリーディ } \\
\text { ング量 } \\
\left(\mathrm{cm}^{3} / \mathrm{cm}^{2}\right)\end{array}$} & \multirow{2}{*}{\multicolumn{2}{|c|}{$\begin{array}{l}\text { 圧縮強度 } \quad\left(\mathrm{N} / \mathrm{mm}^{2}\right) \\
\text { 材齢7日 }\end{array}$}} \\
\hline & & & & & & & & & \\
\hline \multicolumn{3}{|c|}{ 基準コンクリート $($ - ') } & - & 1.0 & 17.0 & 3.9 & 0.27 & 22.2 & 29.3 \\
\hline \multirow{15}{*}{ 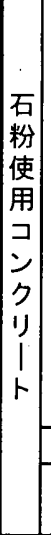 } & \multirow{12}{*}{ 砕石粉 } & DR-1 & 1.4. & 1.0 & 18.0 & 5.3 & 0.08 & 23.2 & 31.0 \\
\hline & & DR-3 & 2.5 & 1.0 & 18.5 & 5.5 & 0.12 & 22.1 & 28.7 \\
\hline & & DR-4 & 3.3 & 1.0 & 18.0 & 5.0 & 0.10 & 23.1 & 30.6 \\
\hline & & DU-4 & 0.9 & 1.0 & 18.5 . & 4.4 & 0.09 & 24.5 & 31.9 \\
\hline & & DU-5 & 1.2 & 1.0 & 17.5 & 4.5 & 0.10 & 24.1 & 31.8 \\
\hline & & DU-6 & 0.9 & 1.0 & 18.0 & 4.5 & 0.11 & 24.1 & 32.1 \\
\hline & & DU-7 & 0.5 & 1.0 & 18.5 & 4.6 & 0.10 & 24.3 & 31.6 \\
\hline & & DU-8 & 2.2 & 1.0 & 18.0 & 4.7 & 0.09 & 23.6 & 31.4 \\
\hline & & DU -11 & 5.0 & 1.0 & 17.5 & 4.9 & 0.08 & 22.8 & 30.0 \\
\hline & & $\mathrm{DU}-13$ & 1.0 & 1.0 & 18.0 & 4.2 & 0.08 & 23.3 & 31.3 \\
\hline & & DU-14 & 0.7 & 1.0 & 18.5 & 5.0 & 0.09 & 23.7 & 31.7 \\
\hline & & DU-19 & 1.2 & 1.0 & 17.5 & 5.3 & 0.09 & 22.4 & 28.7 \\
\hline & 石灰石粉 & $\mathrm{FL}-1$ & 0.1 & 1.0 & 19.0 & 5.2 & 0.18 & 22.8 & 29.4 \\
\hline & \multirow{2}{*}{ 粘土粉 } & $\mathrm{FC}-1$ & 5.9 & 2.8 & 19.0 & 3.8 & 0.09 & 23.9 & 32.8 \\
\hline & & $\mathrm{FC}-2$ & 3.8 & 2.0 & 19.5 & 3.7 & 0.11 & 25.2 & 32.4 \\
\hline
\end{tabular}

表5 コンクリートの調合

\begin{tabular}{|c|c|c|c|c|c|c|c|c|c|c|}
\hline \multirow[b]{2}{*}{ コンクリートの種類 } & \multirow{2}{*}{$\begin{array}{c}\text { 目 摽 } \\
\text { スランプ } \\
(\mathrm{cm})\end{array}$} & \multirow{2}{*}{$\begin{array}{c}\text { 目 標 } \\
\text { 空気量 } \\
(\%) \\
\end{array}$} & \multirow{2}{*}{$\begin{array}{c}\text { 水セx忖比 } \\
W / C \\
(\%)\end{array}$} & \multirow{2}{*}{\begin{tabular}{|c} 
細骨材率 \\
s/a \\
$(\%)$
\end{tabular}} & \multicolumn{5}{|c|}{ 単 位 量 $\left(\mathrm{m}^{3} / \mathrm{m}^{3}\right)$} & \multirow{2}{*}{$\begin{array}{c}\text { 混和郕 } \\
\text { adm } \\
(C+F) \times \%\end{array}$} \\
\hline & & & & & $\begin{array}{l}\text { 水 } \\
W\end{array}$ & $\left|\begin{array}{c}\text { セメント } \\
c\end{array}\right|$ & $\begin{array}{c}\text { 砕石粉 } \\
F\end{array}$ & $\begin{array}{c}\text { 細骨材 } \\
\text { S }\end{array}$ & $\begin{array}{c}\text { 粗骨材 } \\
\text { G. }\end{array}$ & \\
\hline 基準コンクリート & \multirow{2}{*}{$18 \pm 1$} & \multirow{2}{*}{ 4. $5 \pm 1$} & \multirow{2}{*}{60.0} & \multirow{2}{*}{47.5} & \multirow{2}{*}{0.180} & \multirow{2}{*}{0.095} & - & 0.323. & \multirow{2}{*}{ 0. 357} & \multirow{2}{*}{ 1. 0} \\
\hline 石粉使用コンクリート & & & & & & & 0.016 & 0.307 & & \\
\hline
\end{tabular}




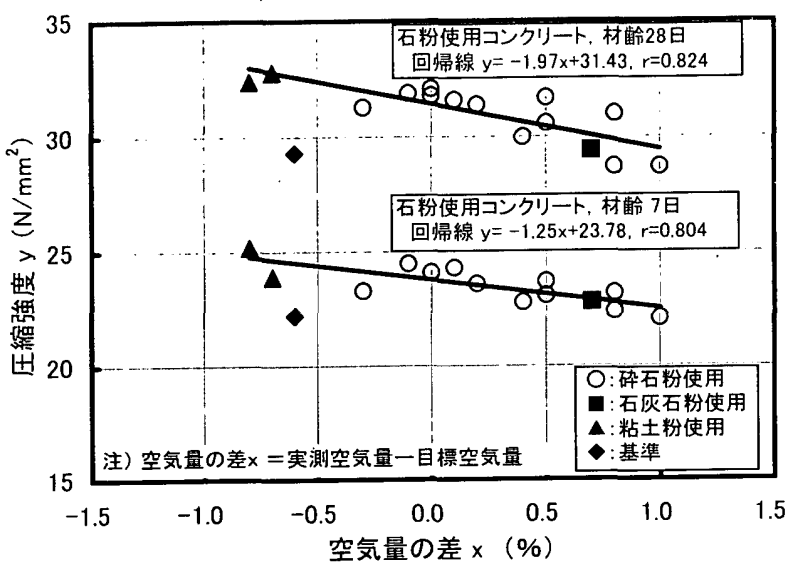

図 12 コンクリート圧縮強度と空気量の差の関係

コンクリートの圧縮強度と石粉を使用した空気量との間には負の 一次相関関係があり、直線回帰式から求めた空気量 $1 \%$ の増加に対 するコンクリートの圧縮強度低下率は、材歯令 7 日で $5.2 \%$ 、材秢 28 日 6.3\%であった。なお、同図から石粉使用コンクリートの圧縮強 度は、基準コンクリートに比べてやや大きくなる傾向が窥えた。

石粉使用コンクリートの圧縮強度について、前述の直線回帰式か ら空気量 $4.5 \%$ 相当の圧縮強度に補正し表 7 に示す。この石粉使用 コンクリートの空気量で補正した圧縮強度を Zスコアで評価 13)す ると、砕石粉 DU·19 を用いたコンクリートの材齢 28 日圧縮強度試 験結果 No.1の z スコアが-2.36 となったが、その他の z スコアは すべて約 95\%信頼区間内と考えられる \pm 2 の範囲内に位置した。な お、砕石粉 DU-19 を用いたコンクリートについても供試体 3 体の 平均值の $\mathrm{z}$ スコアは 2 の範囲内となる。また、圧縮強度試験にお

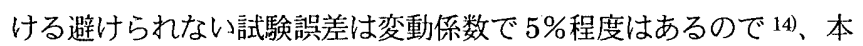
実験の石粉使用コンクリートの圧縮強度は、いずれの石粉を使用し た場合にも有意な差はないと評価することができる。また、この砕 石粉使用コンクリートの圧縮試験結果からは、吸着水率をもとにそ れぞれの石粉の含水状態に応じて水量を補正したことによる不合理 な点は認められなかった。

\section{6. 結論}

砕石粉をコンクリート用混和材として使用する際に必要となる、 単位水量算出のための含水状態の指標および密度の試験方法につい て検討した結果、以下のことが考察された。

(1) 細骨材中の粒径が小さな粒度群では、JIS A 1109 による吸水率 はその粒子の表面形状の影響を強く受ける。

(2) 粒子の水の存在形態から、フレッシュコンクリート中で砕石粉 の粒子内部とみなされるのは結合水量と吸着水量であると考え られ、吸着水量はコンクリート骨材でいう吸水率に相当する。

(3) コンクリート用混和材として用いる場合の、砕石粉の密度の測 定には、JIS R 5201 に規定されている Le Chatelier 比重びん 法が適用できる。

(4) 石粉の吸着水率および密度は; 砕石粉の品質を判定する指標と しても利用できる可能性がある。

(5) 今回のコンクリートによる実験では、砕石粉を使用する際に上 記の吸着水率および密度を適用したことによる不合理な点は認 められなかった。

\section{表 7 石粉使用コンクリートの圧絔強度試験結果詳細}

\begin{tabular}{|c|c|c|c|c|c|c|c|}
\hline \multicolumn{2}{|c|}{$\begin{array}{l}\text { 石粉使用コンク } \\
\text { リートの種類 }\end{array}$} & \multicolumn{2}{|c|}{ 在縮強度 } & \multicolumn{4}{|c|}{ 空気量 $4.5 \%$ 相当に補正した圧縮強度 } \\
\hline $\begin{array}{l}\text { 石粉の } \\
\text { 種類 }\end{array}$ & $\begin{array}{l}\text { 供試体 } \\
\text { 番号 }\end{array}$ & $\begin{array}{l}\text { 材郻 7日 } \\
\left(\mathrm{N} / \mathrm{mm}^{2}\right) \\
\end{array}$ & $\begin{array}{l}\text { 材略令28日 } \\
\left(\mathrm{N} / \mathrm{mm}^{2}\right)\end{array}$ & $\begin{array}{l}\text { 材魿 7日 } \\
\left(\mathrm{N} / \mathrm{mm}^{2}\right) \\
\end{array}$ & Zスコア & $\begin{array}{l}\text { 材䤅28日 } \\
\left(\mathrm{N} / \mathrm{mm}^{2}\right)\end{array}$ & $z ス コ P$ \\
\hline \multirow{3}{*}{ DR-1 } & No. 1 & 23.1 & 31.1 & 24.1 & 0.30 & 32.7 & 1.46 \\
\hline & No. 2 & $23 . \overline{0}$ & 31.1 & 24.0 & 0.15 & 32.7 & 1.46 \\
\hline & No. 3 & 23.4 & 30.9 & $24 . \dot{4}$ & 0.75 & 32.5 & 1.24 \\
\hline \multirow{3}{*}{ DR-3 } & No. 1 & 22.2 & 28.4 & 23.4. & -0.75 & 30.2 & -1.35 \\
\hline & No. 2 & 22.5 & 28.9 & 23.7 & -0.30 & 30.7 & -0.79 \\
\hline & $\mathrm{No} .3$ & 21.8 & 29.0 & 23.0 & -1.34 & 30.8 & -0.67 \\
\hline \multirow{3}{*}{ DR-4 } & No.1 & 22.8 & 30.6 & 23.4 & -0.75 & 31.6 & 0.22 \\
\hline & No. 2 & 23.5 & 30.3 & 24.1 & 0.30 & 313 & -0.11 \\
\hline & No. 3 & 23.0 & 30.8 & 23.6 & $-0 . \overline{45}$ & 31.8 & 0.45 \\
\hline \multirow{3}{*}{ DU-4 } & No. 1 & 24.4 & 32.2 & 24.3 & 0.60 & 32.0 & 0.67 \\
\hline & No.2 & 24.4 & 31.7 & 24.3 & 0.60 & 31.5 & 0.11 \\
\hline & No. 3 & 24.6 & 31.7 & 24.5 & 0.90 & 31.5 & 0.11 \\
\hline \multirow{3}{*}{ DU-5 } & No. 1 & 24.2 & 32.2 & 24.2 & $0 . \overline{45}$ & 32.2 & 0.90 \\
\hline & No.2 & 24.3 & .31 .7 & 24.3 & 0.60 & 31.7 & 0.34 \\
\hline & No.3 & 23.9 & 31.3 & 23.9 & 0.00 & 31.3 & -0.11 \\
\hline \multirow{3}{*}{ DU-6 } & No.1 & 24.4 & 32.5 & 24.4 & 0.75 & 32.5 & 1.24 \\
\hline & No.2 & 23.9 & 32.0 & 23.9 & 0.00 & 32.0 & 0.67 \\
\hline & No.3 & 23.9 & 31.9 & 23.9 & 0.00 & 31.9 & 0.56 \\
\hline \multirow{3}{*}{ DU-7 } & No. 1 & 24.4 & 32.2 & 24.5 & 0.90 & 32.4 & 1.12 \\
\hline & No.2 & 24.2 & 31.5 & 24.3 & 0.60 & 31.7 & 0.34 \\
\hline & No.3 & 24.4 & 31.2 & 24.5 & 0.90 & 31.4 & 0.00 \\
\hline \multirow{3}{*}{ DU-8 } & No. 1 & 23.9 & 31.2 & 24.2 & 0.45 & 31.6 & 0.22 \\
\hline & No. 2 & 23.3 & 31.6 & 23.5 & -0.60 & 32.0 & 0.67 \\
\hline & No.3 & 23.6 & 31.5 & 23.9 & 0.00 & 31.9 & 0.56 \\
\hline \multirow{3}{*}{ DU-11 } & No.1 & 22.9 & 30.6 & 23.4 & -0.75 & 31.4 & 0.00 \\
\hline & No. 2 & 22.7 & 29.3 & 23.2 & -1.04 & 30.0 & -1.57 \\
\hline & No. 3 & 22.6 & 30.0 & 23.1 & -1.19 & 30.8 & -0.67 \\
\hline \multirow{3}{*}{ DU-13 } & No. 1 & 23.1 & 31.6 & 22.7 & -1.79 & 31.0 & -0.45 \\
\hline & No. 2 & 23.4 & 30.9 & 23.0 & -1.34 & 30.3 & -1.24 \\
\hline & No.3 & 23.4 & 31.2 & 23.0 & -1.34 & 30.6 & -0.90 \\
\hline \multirow{3}{*}{ DU-14 } & No. 1 & 24.2 & 31.9 & 24.8 & 1.34 & 32.9 & 1.69 \\
\hline & No.2 & 23.4 & 31.5 & 24.0 & 0.15 & 32.5 & 1.24 \\
\hline & No.3 & 23.5 & 31.7 & 24.1 & 0.30 & 32.7 & 1.46 \\
\hline \multirow{3}{*}{ DU-19 } & No. 1 & 21.8 & 27.9 & 22.7 & -1.79 & 29.3 & -2.36 \\
\hline & No.2 & 22.5 & 29.5 & 23.5 & -0.60 & 31.0 & -0.45 \\
\hline & No.3 & 22.8 & 28.7 & 23.8 & -0.15 & 30.1 & -1.46 \\
\hline \multirow{3}{*}{$\mathrm{FL}-1$} & No. 1 & 22.8 & 29.9 & 23.6 & -0.45 & 31.2 & -0.22 \\
\hline & No.2 & 22.8 & 29.7 & 23.6 & -0.45 & 31.0 & -0.45 \\
\hline & No.3 & 23.0 & 28.6 & 23.9 & 0.00 & 29.9 & -1.69 \\
\hline \multirow{3}{*}{$\mathrm{FC}-1$} & No. 1 & 24.2 & 32.2 & 23.3 & -0.90 & 30.8 & -0.67 \\
\hline & No.2 & 23.9 & 32.6 & 23.0 & -1.34 & 31.2 & -0.22 \\
\hline & No.3 & 23.5 & 33.3 & 22.6 & -1.94 & 31.8 & 0.45 \\
\hline \multirow{3}{*}{$\mathrm{FC}-2$} & No. 1 & 24.6 & 32.8 & 23.6 & -0.45 & 31.1 & -0.34 \\
\hline & No. 2 & 25.2 & 32.2 & 24.1 & 0.30 & 30.6 & -0.90 \\
\hline & No.3 & 25.7 & 32.2 & 24.6 . & 1.04 & 30.6 & -0.90 \\
\hline \multicolumn{2}{|c|}{ 平均値 $\left(\mathrm{N} / \mathrm{mm}^{2}\right)$} & 23.5 & 31.0 & 23.8 & - & 31.4 & - \\
\hline 標準偏者 & $\left(\mathrm{N} / \mathrm{mm}^{2}\right)$ & 0.85 & 1.30 & 0.56 & - & 0.85 & - \\
\hline 変動信 & 数(\%) & 3.62 & 4.19 & 2.35 & - & 2.71 & - \\
\hline メジア: & $\left(\mathrm{N} / \mathrm{mm}^{2}\right)$ & - & - & 23.9 & - & 31.4 & $\overline{-}$ \\
\hline IQR ( & $\left.1 / \mathrm{mm}^{2}\right)$ & - & - & 0.67 & - & 0.89 & - \\
\hline 頑健変重 & 係数 $(\%)$ & - & - & 2.80 & - & 2.83 & - \\
\hline
\end{tabular}

\section{<参考文献 $>$}

1) 近畿砕石協同組合 : 岩石資源有効利用推進調查報告書 砕石粉のコンクリート用混和材 への有效利用、1992 年

2）大橋正治,田村博,谷川恭雄 : コンクリート用混和材としての砕石粉の有効利用に関する 研究一砕石粉の粒度, 比表面積および粘土分量試験方法に関する検討一, 日本建築学会 構造系諭文集 第 532 号, 2000 年 6 月.

3) 日本建築学会 : 建築工事標準仕様書・同解説 JASS 5 鉄筋コンクリート工事, 1997 年. 4) 日本工業規格 JS A 1109-1999 細骨材の密度及び吸水率試験方法

5) 岡田清,六車熙編集 : 改訂新版 コンクリート工学ハンドブック，朝倉書店，1981 年. 6) 紹体工学会編、粉体工学便覽、日刊工業新聞社、1986 年

7) 後藤知以,今井広武 : 砂の実積率におよぼす粒度の影響について、日本建築学会北海道 支部研究報告集 No.42, 昭和 50 年 3 月

8) 大井孝和,小池狭千朗,加藤善之助 : 三粒径グループから成る骨材の充填について，日本 建築学会大会学術講演梗概集, 昭和 53 年 9 月。

9）日本工業規格ＪS R 5201-1997 セメントの物理試験方法 。

10）日本工業規格 JSA 1202-1999 土粒子の密度試験方法。

11)笠井芳夫,池田尚治編著 : コンクリートの試験方法，技術書院，1993 年.

12）日本工業規格 JS A 5308-1998 レディーミクストコンクリート 付属畫 I (規定)レデ イーミクストコンクリート用骨材.

13）通商産業省製品評価技術センター:工業標準化法に基づく試験事業者認定制度 (JNLLA)に 倸る技能試験最終報告書建築材料分野(コンクリート圧縮強度試験)、平成 12 年12月。 14）日本建築学会 : 建築工事標準仕様書・同解説 JASS 5 鉄筋コンクリート工事, 1991 年. 